\section{Role of microRNAs in solid tumors}

\author{
Rie Hamano, Hideshi Ishii, Hiroshi \\ Miyata, Yuichiro Doki, Masaki Mori \\ Department of Gastroenterological \\ Surgery, Osaka University Graduate \\ School of Medicine, Osaka, Japan
}

\section{Abstract}

Accumulating experimental evidence indicates that microRNAs play important roles in various biological processes, such as cell differentiation, proliferation, metabolism and apoptosis. In addition, several reports concluded that altered expression of specific microRNA genes contributes to the initiation and progression of cancer. Here, we summarize the current knowledge about aberrant expression of various microRNAs in human solid cancers (e.g., lung, breast, and gastric cancers), their target proteins, and the relationship between their expression and response to chemotherapies. We also review the potential for using microRNAs as biomarkers for the diagnosis and cancer therapy. The development of treatment strategies against human solid cancers based on the profile and/or certain features of microRNAs is promising.

\section{What is microRNA?}

MicroRNAs are noncoding, single-stranded RNAs, 18-25 nucleotides long, and were first reported in Caenorhabditis elegans in $1993 .{ }^{1}$ Subsequent studies led to the identification of microRNAs in human RNA, ${ }^{2}$ as well as to the understanding of their mechanisms of action. Most human miRNAs are found within introns of either protein-coding or noncoding mRNA transcripts, ${ }^{3}$ and they do not code for any protein although they are RNA sequences.

MicroRNA genes are generally transcribed by RNA polymerase II in the nucleus to form pri-miRNA transcripts. These are processed into pre-miRNAs by a microprocessor complex, which contains the Rnase III enzyme Drosha ${ }^{4}$ and DGCR8. ${ }^{5}$ Exportin5 and a RanGTP ${ }^{6}$ transport the pre-miRNAs from the nucleus to the cytoplasm, where they are further processed by the RNAase III enzyme Dicer. ${ }^{7}$ The mature miRNA is retained in RISC (RNA-induced silencing complex $)^{8}$ and it is currently understood that microRNAs mainly bind to the 3 ' untranslated region (UTR) of their target mRNAs. However, recent studies have reported that microRNAs do not only bind to 3'UTR but also to $5 \mathrm{UTR}^{9,10}$ or open reading frame $(\mathrm{ORF})^{11,12}$ of the target mRNA. By binding to the 3'UTRs, 5'UTR or ORF of target mRNAs, microRNAs regulate the translation of proteins from mRNA or degrade the mRNA itself. ${ }^{13}$ While microRNAs are thought to repress the translation of target mRNAs, recent results demonstrated that microRNAs can activate the expression of the target genes. ${ }^{14}$ In the same study, microRNA was reported to be essential for translation activation under growth arrest conditions. Regulation of translation by microRNAs might change from repression to activation depending on the cell cycle.

In addition, because microRNA can bind even to mRNA that is not partially complementary, ${ }^{15}$ microRNA and mRNA do not correspond one-to-one ${ }^{16}$ such that one microRNA may regulate several mRNAs or one mRNA may be regulated by several microRNAs. For example, in human gliomas, miR-34a inhibits the expression of multiple oncogenes (e.g., c-Met, Notch1/Notch-2 and CDK6) by binding to their 3'UTR and suppressing tumor growth. ${ }^{17}$ Thus, these microRNAs potentially regulate approximately $30 \%$ of all genes encoding human proteins ${ }^{18}$ and appear to achieve a wide range of cell functions, such as cell generation, differentiation, and proliferation.

\section{Aberrant expression of microRNAs in solid cancers}

With regard to the relationship between microRNA and cancer, the initial studies reported that B-cell chronic lymphocytic leukemia is associated with downregulation or deletion of miR-15 and miR-16 genes. ${ }^{19}$ Other studies subsequently showed that more than half of the microRNAs were located near the unstable DNA region, where chromosomal deletions or amplifications associated with cancer in large the majority of cancer cells. ${ }^{20}$ Thus, in cancer tissues, detailed profiling of microRNA should be informative and useful for evaluation of the cancer properties. In fact, it is reported that the expression levels of microRNAs vary widely depending on the cancer type and degree of differentiation ${ }^{9}$ and that cancers can be even classified according to the microRNA profile, but not the mRNA profile. ${ }^{21}$

MicroRNAs include both microRNAs that act to inhibit cancer and microRNAs that conversely target tumor suppressor genes and act like oncogenes. To date, numerous reports have examined the aberrant expression of microRNAs and the association between the level of microRNA expression and prognosis in a number of human carcinomas. Table 1 lists the major microRNAs with reported aberrant
Correspondence: Masaki Mori, Department of Gastroenterological Surgery, Osaka University Graduate School of Medicine, 2-2, Yamadaoka, Suita, Osaka 565-0871, Japan.

Tel: +81.6.6879.3251 - Fax: +81.6.6879-.3259.

E-mail: mmori@gesurg.med.osaka-u.ac.jp

Key words: microRNA, cancer, anti-cancer therapy, biomarker.

Conflict of interest: the authors report no conflicts of interest.

Received for publication: 16 November 2010 .

Revision received: 13 January 2011.

Accepted for publication: 17 January 2011.

This work is licensed under a Creative Commons Attribution 3.0 License (by-nc 3.0).

(C) Copyright R. Hamano et al., 2011

Licensee PAGEPress, Italy

Journal of Nucleic Acids Investigation 2011; 2:e2 doi:10.4081/jnai.2011.e2

expression in solid cancers. To study the relationship between microRNAs and cancer, it is important to examine not only aberrant expressions of microRNAs in carcinomas but also the gene targeted by these microRNAs and to understand their overall roles in cancer. For example, miR-21 is a typical oncogene microRNA whose aberrant expression has been confirmed in various cancers such as breast cancer, ${ }^{22}$ lung cancer, ${ }^{23}$ esophageal cancer, ${ }^{24}$ colorectal cancer, ${ }^{25}$ pancreatic cancer, ${ }^{26}$ and hepatocellular carcinoma. ${ }^{27}$ Interestingly, the $\mathrm{Bcl}-2^{22}$ and $\mathrm{PTEN}^{27}$ genes are target genes of miR-21, and the oncogene-like function of miR-21 is mediated through the suppression of such tumor suppressor genes.

\section{Lung cancer}

One major microRNA, the let-7 family, was first reported to alter the prognosis of patients with lung cancer. ${ }^{28}$ Oncogenes such as RAS 29) and $\mathrm{HMGA}^{30}$ are already known as target genes of the let-7 family. In 2008, the first microRNAknockout mouse was reported, the miR-17-92 knockout mouse, which exhibited hypoplasia of the lungs and B lymphocytes. ${ }^{31}$ MiR-17-92 may also be involved in the process of lung carcinogenesis, and further studies are desirable. In fact, several reports have described the relationship between the expression of miR-17-92 and lung cancer. ${ }^{32-35}$ On the other hand, the expression of microRNA was recently reported to correlate with smoking. ${ }^{36}$ Based on the relationship between smoking and lung cancer, further studies are needed to determine the relationship between smoking and microRNA expression. It is anticipated that such studies will allow the design of new approaches for cancer treatment. 


\section{Breast cancer}

Breast cancer is a major cause of cancer mortality in women, ${ }^{37}$ and one of the cancers most studied in relation to microRNA. The aberrant expression of many microRNAs has been reported (Table 1). Several studies reported the association between stem cells or cancer stem cells and microRNAs, such as the let-7 family, ${ }^{38}$ miR-200c, ${ }^{39}$ and miR-30, ${ }^{40}$ in breast cancer. Furthermore, it is interesting that the number of studies conducted using a murine breast cancer model has been increasing relative to studies on other cancers. One study showed that miR-31 can impede local invasion and suppress metastasis from primary breast tumor in vivo and that the expression level of miR-31 correlates inversely with metastasis in human breast cancer. ${ }^{41}$ Another study found low expression levels for miR-126 and miR-335 in primary human breast tumors and restoration of the expression of these microRNAs significantly reduced bone metastases in vivo. ${ }^{42}$

\section{Esophageal cancer}

Enzymes that contribute to the biogenesis of microRNA in esophageal cancer were first reported in $2006 .{ }^{43}$ However, there are few reports that have described the relationship between esophageal cancer and aberrant expression of microRNA, compared with other solid tumors (Table 1). This may be due to the difficulty in collecting tissue samples from patients with esophageal cancer because esophagectomy is mostly performed in limited number of institutions. In this regard, a recent study using 70 tissue samples of esophageal cancer collected from several centers in three countries found that up-regulation of miR-21 expression and down-regulation of miR-375 expression correlated significantly with poor prognosis. ${ }^{44}$ Further studies are needed to explore the potential therapeutic effects of microRNAs, such as improvement in sensitivity to radio- and chemo-therapy.

\section{Gastric cancer}

The expression of microRNA in gastric cancer was first reported in 2006 in a study that used microarray analysis, ${ }^{45}$ the results showed aberrant expression of 28 microRNAs (22 upregulated and 6 down-regulated). Gastric cancer includes various histopathological subtypes, such as three degrees of differentiation, mucinous, papillary and signet ring cell, and microRNAs are expressed differentially in this cancer according to histopathological subtype. ${ }^{45}$ Thus, detailed analysis based on classification of histopathological types is necessary for proper analysis of aberrant expression of microRNA in gastric cancer. Although the number of studies on microRNA in gastric cancer is smaller than colorectal cancer and breast cancer, reports published in 2010 indicate increased interest in the aberrant expression of microRNA in this type of cancer (Table 1).

\section{Colorectal cancer}

Similar to breast cancer, the expression of microRNA, including aberrant expression, in colorectal cancer has been the topic of several studies (Table 1). For example, among patients with stage II colorectal cancer, those with high expression of miR-320 and miR-498 are considered to have better relapse-free survival than patients with low expression. ${ }^{46}$ The same report indicated that analysis of the expression of a combination of several microRNAs can predict relapse with $81 \%$ accuracy rate, suggesting the potential of microRNA as a biomarker of recurrence. Another feature of colorectal cancer is the association between the expression of microRNAs and the p53 pathway ${ }^{47-51}$

\section{Hepatocellular carcinoma}

Several reports have described the aberrant expression of microRNAs in hepatocellular carcinoma (HCC) (Table 1). The expression of microRNA is also reported to be associated with HBV and HCV infections ${ }^{52,53}$ which are closely related to HCC, and the association with hepatocarcinogenesis has been indicated. ${ }^{54}$ Reduced expression of miR-122 in a chimpanzee model of HCV hepatitis/HCC was reported to result in successful control of HCC, 55 and the clinical application to humans is greatly anticipated.

\section{Pancreatic cancer}

Pancreatic cancer is one of the most malignant cancers, and ranks eighth among the causes of death worldwide. ${ }^{37}$ In addition to searching for aberrant expression of microRNA in pancreatic cancer (Table 1), analysis of the clinical significance of microRNA on early detection of cancer and the therapeutic outcome would be desirable. In this regard, it has been reported that profile analysis of microRNA expression can differentiate pancreatic cancer from chronic pancreatitis ${ }^{56}$ which is sometimes difficult to distinguish from pancreatic cancer. In fact, the expression of miR-196a-2 has already been used as a marker for differentiating pancreatic cancer from pancreatitis. ${ }^{57}$ MiR-155 is also reportedly useful for early detection of intraductal papillary mucinous neoplasm (IPMN). ${ }^{58}$

\section{Ovarian cancer}

Although there are numerous reports on the aberrant expression of various microRNAs in ovarian cancer (Table 1), interestingly, there are almost no reports on miR-21, which is a typical proto-oncogene. Several studies examined the relationship between microRNA and sensitivity to cisplatin or paclitaxel chemotherapy, which is often used in clinical settings. For example, among patients with ovarian cancer undergoing cisplatin-based chemotherapy, the complete responders to chemotherapy showed significantly higher expression of let$7 \mathrm{i}$ in their tumors compared with the other patients that did not respond completely, and ovarian cancer cells with overexpression of let7i were more sensitive to cisplatin than those with low expression. ${ }^{59}$

\section{Glioblastoma}

Glioblastoma is one of the highest-grade tumor among human intracranial tumors, and aberrant microRNA expression in glioblastoma has been reported in many studies (Table 1). To improve the prognosis of patients with glioblastoma, the development of biomarkers for early detection of glioblastoma, for example circulating microRNAs, is needed. This is particularly important since glioblastoma respond well to treatment with temozolomide, an oral alkylating agent often used for the treatment of intracranial tumors (Table 2).

\section{Anti-cancer therapy and microRNA}

In addition to the aforementioned studies that identified aberrant expression of microRNAs in various cancers, it is anticipated that novel anticancer therapeutic strategies will be designed in the future that are based on microRNAs, including chemotherapeutic agents, anti-hormone receptor agents and radiotherapy that target specific microRNAs. Furthermore, changes in the expression levels of microRNAs during any such therapy, relative to the baseline (using microarray analysis), could be also used to predict the sensitivity/resistance of tumors to the antitumor agents as well as monitor the response to such treatment.

Table 2-1 shows the relationship between certain microRNAs and the response to chemotherapy. For example, previous studies using microRNA microarray analysis showed down-regulation of 10 microRNAs and up-regulation of two microRNAs in chemoresistant gastric cancer cells compared with parent cells $^{60}$ and down-regulation of two microRNAs and up-regulation of 13 microRNAs in chemoresistant glioblastoma cells compared with parent cells. ${ }^{61}$ Another study found significantly low levels of let-7i expression in chemotherapy-resistant patients. ${ }^{59}$ These studies highlight the potential application of microRNAs to the prediction of the tumor response to chemotherapy.

Table 2-2 also lists few microRNAs that were 
Table 1. Aberrant expression of microRNA in solid cancers.

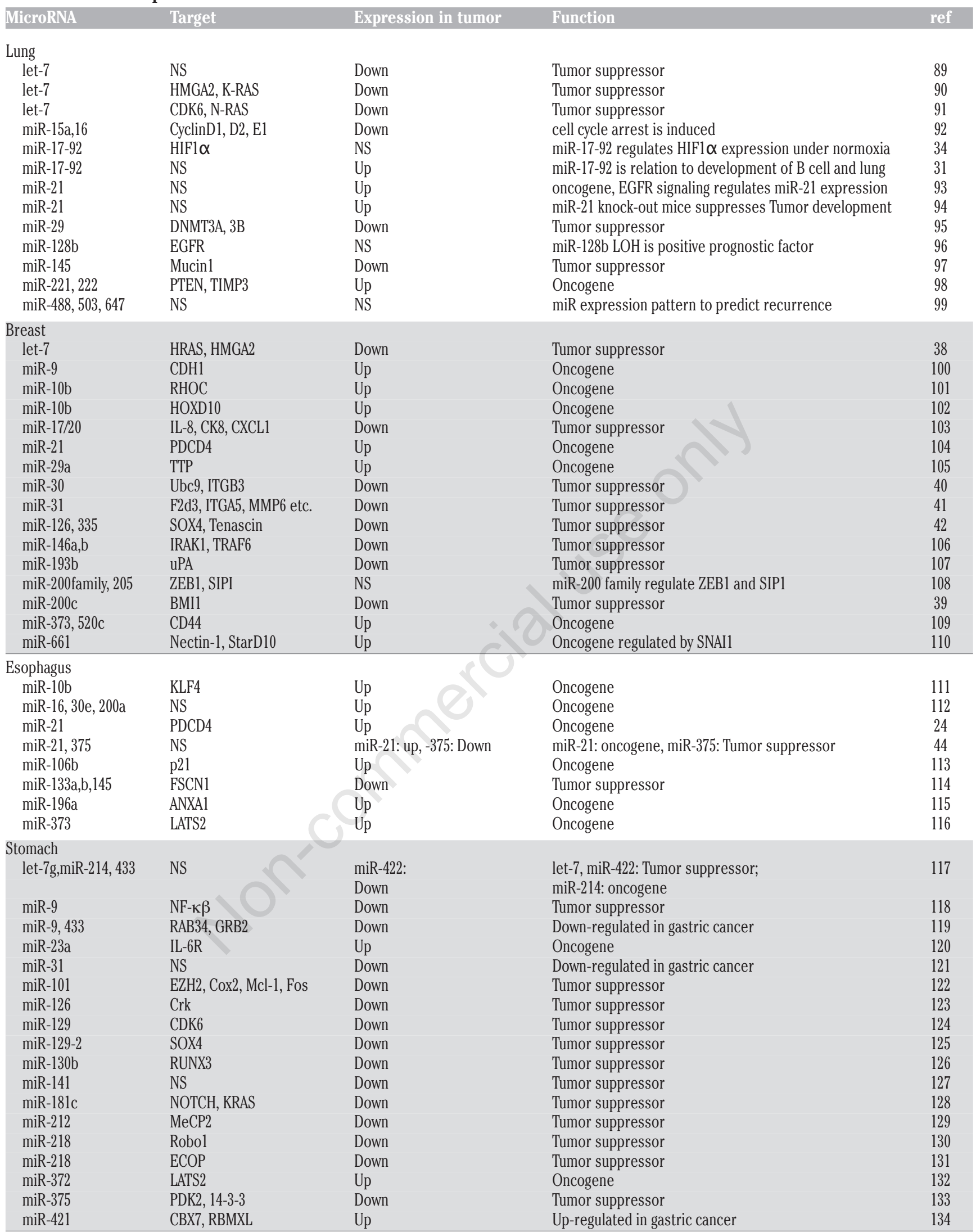


Table 1. Continued from previous page.

\begin{tabular}{|c|c|c|c|c|}
\hline \multicolumn{5}{|l|}{ Colon } \\
\hline miR-16 & Wipl & Down & Down-regulated in colon cancer & 47 \\
\hline miR-18* & KRAS & Down & Tumor suppressor & 135 \\
\hline miR-21 & CDC25A & Up & Oncogene & 136 \\
\hline miR-34a & $\mathrm{E} 2 \mathrm{~F}$ & Down & Tumor suppressor & 137 \\
\hline miR-106a & $\mathrm{E} 2 \mathrm{~F} 1$ & Down & Tumor suppressor & 138 \\
\hline miR-107 & HIF1 $\beta$ & Down & Tumor suppressor & 48 \\
\hline miR-143 & DNMT3A & Down & Tumor suppressor & 139 \\
\hline miR-145 & IRS1 & Down & Tumor suppressor & 140 \\
\hline miR-155 & MSH1, MSH2 & Up & Oncogene & 141 \\
\hline miR-192 & NS & NS & Proliferative effect of miR-192 depends on p53 & 50 \\
\hline miR-196a & NS & Up & Oncogene & 142 \\
\hline miR-320, 498 & NS & Down & Tumor suppressor & 46 \\
\hline $\operatorname{miR}-675$ & $\mathrm{RB}$ & Up & Oncogene & 143 \\
\hline \multicolumn{5}{|l|}{ Liver } \\
\hline miR-18a & $\mathrm{ER} \alpha$ & Up & Oncogene & 144 \\
\hline miR-21 & PTEN & Up & Oncogene & 27 \\
\hline miR-26a & NS & Down & Tumor suppressor & 145 \\
\hline miR-101 & Mcl-1 & Down & Tumor suppressor & 68 \\
\hline miR-122 & CyclinG1 & Down & Tumor suppressor & 146 \\
\hline miR-122 & NS & Down & Tumor suppressor & 147 \\
\hline miR-151 & PhoGD1A & Up & Oncogene & 148 \\
\hline miR-181b & TIMP3 & Up & Oncogene & 149 \\
\hline miR-193b & Mcl-1 & NS & HCV proteins alter miR expressions & 53 \\
\hline miR-196 & Bachl & NS & miR-196 inhibits HCV expression & 54 \\
\hline miR-221 & CDKN1C/p57, CDKN1B/p27 & Up & Oncogene & 150 \\
\hline miR-221 & Bmf & Up & Oncogene & 151 \\
\hline miR-222 & PPP2R2A & Up & Oncogene & 152 \\
\hline miR-223 & STMN1 & Down & Tumor suppressor & 153 \\
\hline \multicolumn{5}{|l|}{ Pancreas } \\
\hline miR-21 & NS & Up & Oncogene & 154 \\
\hline miR-27a & Sprouty2 & Up & Oncogene & 155 \\
\hline miR-96 & KRAS & Down & Tumor suppressor & 156 \\
\hline miR-107 & CDK6 & Down & Tumor suppressor & 157 \\
\hline miR-146a & EGFR, IRAK1, NFK $\beta$, MTA2 & Down & Tumor suppressor & 158 \\
\hline miR-155 & TP53INP1 & Up & Oncogene & 159 \\
\hline miR-196a-2 & NS & Up & Oncogene & 57 \\
\hline miR-210 & EFNA3 & Up & Oncogene & 160 \\
\hline \multicolumn{5}{|l|}{ Ovary } \\
\hline let-7i & NS & & Tumor suppressor & 59 \\
\hline miR-9, 223 & NS & $\begin{array}{l}\text { miR-9: down, } \\
\text { miR-223: down }\end{array}$ & $\begin{array}{l}\text { miR-9: Down-regulated, } \\
\text { miR-223: up-regulated in recurrent ovarian cancer }\end{array}$ & 161 \\
\hline $\operatorname{miR}-15 \mathrm{a}, 16$ & Bmi-1 & Down & Tumor suppressor & 162 \\
\hline miR-20a & APP & Up & Oncogene & 163 \\
\hline miR-27a & NS & Up & Oncogene & 164 \\
\hline miR-31 & CEBPA, STK40, E2F2 & Down & Tumor suppressor & 165 \\
\hline miR-34b, 34c & NS & Down & Tumor suppressor & 166 \\
\hline miR-125a & ARID3B & Up & Oncogene & 167 \\
\hline miR-185 & Sixl & Down & Tumor suppressor & 168 \\
\hline miR-199a & IKK $\beta$ & Down & Tumor suppressor & 169 \\
\hline miR-199a, 214 & NS & Up and down & Twistl regulates miRs & 170 \\
\hline miR-200a, 200b & ZEB1,2 & Up & up-regulated in ovarian cancer & 171 \\
\hline $\operatorname{miR}-210$ & E2F3 & NS & miR-210 is a key regulator of hypoxia & 172 \\
\hline miR-221, 222 & CDKN1C & Down & Tumor suppressor & 173 \\
\hline \multicolumn{5}{|l|}{ Glioblastoma } \\
\hline miR-7 & EGFR & Down & Tumor suppressor & 174 \\
\hline miR-10b & RhoC, uPAR & Up & Oncogene & 175 \\
\hline miR-17-92 & Smad, etc. & Up & Oncogene & 176 \\
\hline miR-17-92 & CTGF & $\mathrm{Up}$ & Oncogene & 177 \\
\hline miR-21 & NS & $\mathrm{Up}$ & Oncogene & 178 \\
\hline miR-26a & PTEN, RB1, MEKK2 & Up & Oncogene & 179 \\
\hline miR-34a & $\mathrm{NC}$ & Down & Tumor suppressor & 17 \\
\hline miR-128 & Bmil & Down & Tumor suppressor & 180 \\
\hline miR-153 & Bcl-2, Mcl-1 & Down & Tumor suppressor & 181 \\
\hline miR-196 & $\mathrm{NC}$ & Up & High expression shows poorer survival. & 182 \\
\hline miR-221, 222 & p27, p57 & Down & Tumor suppressor & 183 \\
\hline miR-222, 339 & ICAM1 & Up & MiRs correlate with CTL-mediated cytolysis & 184 \\
\hline miR-296 & HGS & Up & miR-296 contributes to angiogenesis & 185 \\
\hline
\end{tabular}

NS; not stated 
reported to show changes in their expression during cancer treatment. For example, significant reductions in let-7a and let-7b expression levels, relative to the baseline levels, were noted at $8 \mathrm{~h}$ after irradiation in lung cance, ${ }^{62}$ where a significant increase in miR-34 expression was monitored following irradiation-induced DNA damage $\mathrm{e}^{63}$ in breast cancer tissue. The development of resistance to chemotherapy is also a problem during cancer treatment. In the cancer stem cell theory, the pluripotent and self-replication properties of the stem cells affect resistance to chemotherapy $38,{ }^{64}$ while microRNAs are known to regulate stem cell functions. ${ }^{65-67}$ Thus, microRNAs seem to affect the stability of resistance to antitumor therapies in cancerous tissues. In fact, several recent studies described the correlation between resistance to anticancer drugs and expression of microRNAs known to be involved in stem cell functions (Table 2-2). Furthermore, many of microRNAs are known to enhance sensitivity or reduce the resistance to anti tumor therapy. For example, the hematomas in which miR-101 had been introduced showed higher sensitivity to anticancer agents ${ }^{68}$ and the expression of miR-206 correlated inversely with that of estrogen receptor- $\alpha{ }^{69}$ Table 2-3 lists some MicroRNAs known to influence the sensitivity to anti-cancer therapy.

\section{Regulation of microRNA}

Because microRNA regulate the expression of many mRNAs and microRNAs do not correspond one-to-one to mRNA, a comprehensive analysis is required to understand the regulation of such expression. To gain a better understanding of the overall picture of carcinogenesis, including the function of microRNAs, one should understand the mechanisms involved in the regulation of microRNA expression itself. Previous studies proposed that epigenetic mechanisms and other proteins regu-

Table 2. microRNAs related to sensitivity of anti-cancer therapy.

\begin{tabular}{|c|c|c|c|c|c|}
\hline MicroRNA & Treatment & Target & Function & Year & Ref \\
\hline 2-1. MicroRNAs that & ssociated with re & & & & \\
\hline Stomach & & & & & \\
\hline miR15a,16 & $\begin{array}{l}\text { ADR, VCR, } \\
\text { VP16, CDDP }\end{array}$ & NS & Increase sensitivity & 2008 & 60 \\
\hline \multicolumn{6}{|l|}{ Ovary } \\
\hline let-7i & CDDP & NS & Increase sensitivity & 2008 & 59 \\
\hline Glioblastoma & & & & & \\
\hline miR-195 & Temozolomide & NS & Increase sensitivity & 2010 & 61 \\
\hline \multicolumn{6}{|c|}{$\begin{array}{l}\text { 2-2. MicorRNAs those expressions altered during a therapy } \\
\text { Lung }\end{array}$} \\
\hline let-7b,g & Radiation & NS & Increase sensitivity & 2007 & 62 \\
\hline Several miRs & Radiation & Int J oncol & 22 miRs expression were changed & 2009 & 186 \\
\hline Breast & & & & & \\
\hline miR-34 & Radiation & NS & Decrease sensitivity & 2009 & 63 \\
\hline Pancreas & & & & & \\
\hline $\operatorname{miR}-22$ & Curcumin & ESR1, SP1 & NS & 2008 & 187 \\
\hline \multirow{2}{*}{\multicolumn{6}{|c|}{ 2-3. MicroRNA that influences the sensitivity to anti-cancer therapy }} \\
\hline & & & & & \\
\hline miR-181a, 630 & CDDP & NS & Increase sensitivity & 2010 & 188 \\
\hline miR-181b & CDDP & $\mathrm{Bc} 2$ & Increase sensitivity & 2010 & 189 \\
\hline \multicolumn{6}{|l|}{ Breast } \\
\hline let-7 & Epi-ADM & H-RAS, HMGA & Related to tumor initiating cells & 2007 & 38 \\
\hline Esophagus & & & & & \\
\hline $\begin{array}{l}\text { miR-27a } \\
5-\mathrm{FU}, \mathrm{CDDP}\end{array}$ & ADR, VCR, & Bcl2, MRP1 & Decrease sensitivity & 2010 & 190 \\
\hline miR-296 & As above & Bax & Decrease sensitivity & 2010 & 191 \\
\hline \multicolumn{6}{|l|}{ Stomach } \\
\hline miR-221, 222 & Radiation & NS & Decrease sensitivity & 2010 & 192 \\
\hline miR-451 & Radiation & MIF & Increase sensitivity & 2009 & 193 \\
\hline \multicolumn{6}{|l|}{ Colon } \\
\hline miR-140 & $5-\mathrm{FU}$ & HDAC4 & Decrease sensitivity & 2009 & 194 \\
\hline miR-143 & 5 -FU & NS & Increase sensitivity & 2009 & 195 \\
\hline miR-215 & MTX, TDX & NS & Decrease sensitivity & 2010 & 196 \\
\hline \multicolumn{6}{|l|}{ Liver } \\
\hline miR-26a & IFN $\alpha$ & NS & Decrease sensitivity & 2009 & 197 \\
\hline miR-199a-3p & ADR & mTOR, c-Met & Increase sensitivity & 2010 & 198 \\
\hline \multicolumn{6}{|l|}{ Pancreas } \\
\hline miR-21 & GEM & NS & Decrease sensitivity & 2010 & 199 \\
\hline miR-21 & 5 -FU & NS & Decrease sensitivity & 2010 & 200 \\
\hline miR-21 & GEM & NS & Decrease sensitivity & 2009 & 201 \\
\hline \multicolumn{6}{|l|}{ Ovary } \\
\hline miR-27a & TXL & MDR1 & Decrease sensitivity & 2010 & 202 \\
\hline miR-100 & everolimus & MTOR & Increase sensitivity & 2010 & 203 \\
\hline $\begin{array}{l}\text { miR-200c } \\
\text { Glioblastoma }\end{array}$ & TXL & TUBB3 & Increase sensitivity & 2009 & 204 \\
\hline miR-21 & Temozolomide & Bax, Bcl-2 & Decrease sensitivity & 2010 & 205 \\
\hline miR-21 & VM-26 & LRRFIP1 & Decrease sensitivity & 2009 & 206 \\
\hline
\end{tabular}

CDDP, cisplatin; ADR, doxorubicin; VCR, vincristine; VP16, etoposide; MTX, methotrexate; TDX, thymidylate synthase inhibitor Tomudex; GEM, gemcitabine; TXL, taxol; VM-26, Teniposide; NS. not stated. 
late the expression of microRNAs as described below.

\section{Epigenetic mechanisms}

Epigenetic modification means aberrant gene expression due to DNA methylation or histone deacetylation. DNA methylation occurs in specific genomic areas called CpG-islands, which are commonly present in the promoter area of the gene..$^{70}$ Methylation of CpG-island is triggered by DNA methyltransferases (DNMTs) and histone modifications are catalyzed by histone deacetylases (HDACs) and histone methyltransferases (HMTs). Tumor genes are globally hypomethylated compared with those of normal tissues, ${ }^{71}$ and methylation of $\mathrm{CpG}$ islands in the gene promoter area results in inactivation of tumor suppressor genes. ${ }^{70}$ Thus, epigenetic modifications could be involved in carcinogenesis, in addition to other well-defined genetic mechanisms, such as gene mutations and loss of deficiency of heterozygosity.

It was demonstrated recently that certain genes, in particular those with hypermethylated promoters, require Dicer to maintain the epigenetic status. ${ }^{72}$ As mentioned above, Dicer is a key enzyme in microRNA biogenesis. That is a first report that shows the correlation between epigenetic changes of DNA and microRNAs.

Then, Several other studies have reported that epigenetic mechanisms regulate the expression levels of microRNAs. For example, the first report in $2006^{73}$ showed that abnormal methylation correlates with miR-127 expression in several cancer cells. Although miR-127 is not expressed in cancer cells, strong upregulation of this microRNA was noted after treatment with chromatin-modifying drugs (which are also DNA demethylating agents and HDAC inhibitors). Another study showed that the oncoprotein AML1/ETO, an acute myeloid leukemia-associated fusion protein, induced heterochromatic silencing of miR-223 by recruiting DNMTs and HDACl activities. ${ }^{74}$ These results point to a complex epigenetic regulation of microRNAs. Table 3-1 lists a group of microRNAs known to be regulated by epigenetic mechanism.

On the other hand, new evidence suggests that microRNAs can control the expression levels of DNMTs and HDACs. For example, microRNA members of the miR-29 family directly target DNMT3A and DNMT3B. Enforced expression of the miR-29 family induced reexpression of methylation-silenced tumor suppressor genes in lung cancer cells, which resulted in inhibition of cancer growth in xenograft models. ${ }^{75}$ Other studies showed that miR-1 directly targeted HDAC- 4 in murine myoblasts $^{76}$ while miR449a regulated cell growth by repressing HDAC-1 expression in human prostate cancer cells. ${ }^{77}$ Table $3-2$ lists few microRNAs known to control epigenetic mechanisms.

The above studies enhance our understanding of aberrant epigenetic mechanisms in cancers and may prove useful in identifying new targets for cancer therapy.

\section{Regulation by other factors}

Among the various families of microRNAs, the let-7 family, which is known to have tumor suppressor function, is under the control of LIN28, which is overexpressed in germ cells by RNA-binding proteins, at the stage of Drosha enzyme processing. ${ }^{78}$ The latter study indicated the specificity of the regulatory mechanism of LIN28 to the let-7 family by demonstrating the lack of any inhibitory effects on other microRNA. Dicer, another enzyme involved in the processing of microRNAs, also inhibits the let-7 family and forms a negative feedback loop with let-7 family. ${ }^{79}$ Other studies reported the regulation of microRNAs by other transcription factors, such as $\mathrm{p} 53^{80}$ and c-myc, ${ }^{81}$ suggesting that many factors are intricately involved in the mechanisms that regulate microRNAs in cancers. The number of microRNA-related regulatory factors reported to date is not very large, but it is expected to expand exponentially in the future.

\section{MicroRNAs as biomarkers for cancer}

Although many aspects of microRNA formation in the cell remain unclear, it is becoming evident that microRNAs are more stable in the cells than mRNA. Accordingly, it is anticipated that microRNAs may serve as biomarkers of cancer better than mRNA. Historically, intrinsic microRNA levels in the circulation were

Table 3. microRNAs that are regulated by epigenetic gene silencing.

\begin{tabular}{|c|c|c|c|c|c|}
\hline MicroRNA & Cancer type & Target & Detail & Year & Ref \\
\hline \multicolumn{6}{|c|}{ 3-1. Some microRNAs of which expression controlled by epigenetic mechanism } \\
\hline let-7a-3 & Ovary & NS & let-7a-3 methylation is associated with survival & 2007 & 207 \\
\hline miR-1 & Liver & FoxP1, MET, & Overexpression in cells treated with 5- AZA & 2008 & 208 \\
\hline miR-9-1 & Breast & NS & Overexpression in cells treated with 5-AZA & 2008 & 209 \\
\hline $\mathrm{miR}-9,34 \mathrm{~b} / \mathrm{c}, 148 \mathrm{a}$ & Various types & oncogenes & Overexpression in cells treated with 5-AZA & 2008 & 210 \\
\hline miR-9, 129,137 & Colon & NS & Overexpression in cells treated with 5- AZA & 2009 & 211 \\
\hline miR-34b, $-34 c$ & Colon & BTG4 & miR-34b/c methylation is frequently observed in cancer cells & 2008 & 212 \\
\hline miR-124a & Colon & CDK6 & Overexpression in cells treated with 5-AZA & 2007 & 213 \\
\hline miR-127 & Bladder & BCL6 & Overexpression in cells treated with 5-AZA & 2006 & 73 \\
\hline miR-129-2 & Ovary & SOX2 & Overexpression in cells treated with epigenetic drugs & 2009 & 214 \\
\hline miR-137a & Colon & LSD1 & miR-137 methylation is specific for cancer & 2010 & 215 \\
\hline miR-223 & Leukemia & NS & AML1/ETO induced heterochromatic silencing of miR-223 & 2007 & 74 \\
\hline miR-370 & Biliary duct & MAP3К8 & Overexpression in cells treated with 5-AZA & 2008 & 216 \\
\hline miR-512-5p & Stomach & Mcl-1 & Overexpression in cells treated with 5- AZA & 2009 & 217 \\
\hline \multicolumn{6}{|c|}{ 3-2. Some microRNAs that controlls epigenetic mechanism } \\
\hline miR-1 & $\begin{array}{l}\text { Myoblast } \\
\text { (not malignant) }\end{array}$ & HDAC-4 & MiR-1 represses HDAC-4 & 2006 & 76 \\
\hline miR-29 family & Lung & DNMT3a, 3b & $\begin{array}{l}\text { Enforced expression restores normal patterns } \\
\text { of DNA methylation }\end{array}$ & 2007 & 75 \\
\hline miR-29b & Leukemia & DNMT3a, 3b & $\begin{array}{l}\text { Enforced expression restores normal patterns } \\
\text { of DNA methylation }\end{array}$ & 2009 & 218 \\
\hline miR-148a, b & Various types & DNMT3b & MiR-148 represses DNMT3b & 2008 & 219 \\
\hline MiR-449 & Prostate & HDAC-1 & MiR-449 directly targets HDAC-1 & 2009 & 77 \\
\hline
\end{tabular}


found to be relatively stable against endogeneous RNAase. ${ }^{82}$ Subsequent studies reported higher blood miR-195 and let-7 expression levels in patients with breast cancer compared with healthy subjects and that these expression levels fell after surgical excision of the tumor. ${ }^{83}$ Furthermore, the expression levels of miR-29a and miR-92a were also found to increase with the stage of colorectal cancer, ${ }^{84}$ suggesting their potential suitability as a cancer screening tool.

Recent studies have reported measurement of microRNAs in other body fluids in addition to blood, such as feces ${ }^{85}$ and sputum. ${ }^{86}$ For example, significantly higher expression levels of miR-21 were found in the sputum of patients with lung cancer compared with healthy subjects, indicating high sensitivity and specificity. ${ }^{87}$ On the other hand, the expression levels of miR-125a and miR-200a in the saliva were significantly lower in patients with oral cancer than healthy subjects. ${ }^{88}$ Further studies are needed to design simple and noninvasive assays that accurately measure microRNAs collected from human tissues. Such methods will be helpful for screening of cancer or assessment of the therapeutic effects of anti-cancer treatment.

\section{Future perspective of microRNA}

As noted earlier, microRNA are expected to play a major role in the future as biomarkers for screening cancer, predicting response to therapies, and assessing the effect of treatment.

Progress is also anticipated in the development of new microRNA-based anti-cancer therapies. Such therapies could be designed to restrict cancer growth by applying the mRNA regulatory function of microRNA to inhibit oncogenes or activate tumor suppressor genes. Alternatively, new therapies could be designed based on the finding of increased potency of standard chemotherapies when combined with microRNAs.

We are only just beginning to understand microRNAs and their hidden potential. Worldwide research on microRNAs, including clinical application, is currently underway. Treatment strategies against solid cancers based on profile or features of microRNAs are expected to be developed in the near future.

\section{References}

1. Lee RC, Feinbaum RL, Ambros V. The C. elegans heterochronic gene lin-4 encodes small RNAs with antisense complemen- tarity to lin-14. Cell 1993;75:843-54.

2. Lagos-Quintana M, Rauhut R, Lendeckel $\mathrm{W}$, Tuschl T. Identification of novel genes coding for small expressed RNAs. Science 2001;294:853-8.

3. Rodriguez A, Griffiths-Jones S, Ashurst JL, Bradley A. Identification of mammalian microRNA host genes and transcription units. Genome Res 2004;14:1902-10.

4. Lee Y, Ahn C, Han J, et al. The nuclear RNase III Drosha initiates microRNA processing. Nature 2003;425:415-9.

5. Denli AM, Tops BB, Plasterk RH, et al. Processing of primary microRNAs by the Microprocessor complex. Nature 2004;432:231-5.

6. Bohnsack MT, Czaplinski K, Gorlich D. Exportin 5 is a RanGTP-dependent dsRNA-binding protein that mediates nuclear export of pre-miRNAs. RNA 2004;10:185-91.

7. Hutvágner G, McLachlan J, Pasquinelli $\mathrm{AE}$, et al. A cellular function for the RNAinterference enzyme Dicer in the maturation of the let-7 small temporal RNA. Science 2001;293:834-8.

8. Hutvágner G, Zamore PD. A microRNA in a multiple-turnover RNAi enzyme complex. Science 2002;297:2056-60.

9. Ørom UA, Nielsen FC, Lund AH. MicroRNA-10a binds the 5'UTR of ribosomal protein mRNAs and enhances their translation. Mol Cell 2008;30:460-71.

10. Lytle JR, Yario TA, Steitz JA. Target mRNAs are repressed as efficiently by microRNA-binding sites in the 5' UTR as in the 3' UTR. Proc Natl Acad Sci USA. 2007;104:9667-72.

11. Moretti F, Thermann R, Hentze MW. Mechanism of translational regulation by miR-2 from sites in the $5^{\prime}$ untranslated region or the open reading frame. RNA. 2010;16:2493-502.

12. Qin W, Shi Y, Zhao B, et al. miR-24 regulates apoptosis by targeting the open reading frame (ORF) region of FAF1 in cancer cells. PLoS One 2010;5:e9429.

13. Hutvágner G, Zamore PD. A microRNA in a multiple-turnover RNAi enzyme complex. Science 2002;297:2056-60.

14. Vasudevan S, Tong Y, Steitz JA. Switching from repression to activation: microRNAs can up-regulate translation. Science 2007;318:1931-4.

15. Bartel DP. MicroRNAs: genomics, biogenesis, mechanism, and function. Cell 2004;116:281-97.

16. Lewis BP, Shih IH, Jones-Rhoades MW, et al. Prediction of mammalian microRNA targets. Cell 2003;115:787-98.

17. Li Y, Guessous F, Zhang Y, et al. MicroRNA-34a inhibits glioblastoma growth by targeting multiple oncogenes.
Cancer Res 2009;69:7569-76.

18. Lewis BP, Burge CB, Bartel DP. Conserved seed pairing, often flanked by adenosines, indicates that thousands of human genes are microRNA targets. Cell 2005;120:15-20.

19. Calin GA, Dumitru CD, Shimizu M, et al. Frequent deletions and down-regulation of micro- RNA genes miR15 and miR16 at $13 q 14$ in chronic lymphocytic leukemia. Proc Natl Acad Sci USA 2002;99:15524-9.

20. Calin GA, Sevignani C, Dumitru CD, et al. Human microRNA genes are frequently located at fragile sites and genomic regions involved in cancers. Proc Natl Acad Sci USA 2004;101:2999-3004.

21. Lu J, Getz G, Miska EA, et al. MicroRNA expression profiles classify human cancers. Nature 2005;435:834-8.

22. Si ML, Zhu S, Wu H, et al. miR-21-mediated tumor growth. Oncogene 2007;26:2799-803.

23. Markou A, Tsaroucha EG, Kaklamanis L, et al. Prognostic value of mature microRNA-21 and microRNA-205 overexpression in non-small cell lung cancer by quantitative real-time RT-PCR. Clin Chem 2008;54:1696-704.

24. Hiyoshi Y, Kamohara H, Karashima R, et al. MicroRNA-21 regulates the proliferation and invasion in esophageal squamous cell carcinoma. Clin Cancer Res 2009;15:1915-22.

25. Slaby 0, Svoboda M, Fabian P, et al. Altered expression of miR-21, miR-31, miR-143 and miR-145 is related to clinicopathologic features of colorectal cancer. Oncology 2007;72:397-402.

26. Lee EJ, Gusev Y, Jiang J, et al. Expression profiling identifies microRNA signature in pancreatic cancer. Int $\mathrm{J}$ Cancer 2007; 120:1046-54.

27. Meng F, Henson R, Wehbe-Janek H, et al. MicroRNA-21 regulates expression of the PTEN tumor suppressor gene in human hepatocellular cancer. Gastroenterology 2007;133:647-58.

28. Takamizawa J, Konishi H, Yanagisawa K, et al. Reduced expression of the let-7 microRNAs in human lung cancers in association with shortened postoperative survival. Cancer Res 2004;64:3753-6.

29. Johnson SM, Grosshans H, Shingara J, et al. RAS is regulated by the let-7 microRNA family. Cell 2005;120:635-47.

30. Mayr C, Hemann MT, Bartel DP. Disrupting the pairing between let- 7 and Hmga2 enhances oncogenic transformation. Science 2007;315:1576-9.

31. Ventura A, Young AG, Winslow MM, et al. Targeted deletion reveals essential and overlapping functions of the miR-17 through 92 family of miRNA clusters. Cell 2008;132:875-86. 
32. Hayashita Y, Osada H, Tatematsu Y, et al. A polycistronic microRNA cluster, miR-1792 , is overexpressed in human lung cancers and enhances cell proliferation. Cancer Res 2005;65:9628-32.

33. Matsubara H, Takeuchi T, Nishikawa E, et al. Apoptosis induction by antisense oligonucleotides against miR-17-5p and miR-20a in lung cancers overexpressing miR-17-92. Oncogene 2007;26:6099-105.

34. Taguchi A, Yanagisawa K, Tanaka M, et al. Identification of hypoxia-inducible factor1 alpha as a novel target for miR-17-92 microRNA cluster. Cancer Res 2008;68:5540-5.

35. Ebi H, Sato T, Sugito N, et al. Counterbalance between RB inactivation and miR-17-92 overexpression in reactive oxygen species and DNA damage induction in lung cancers. Oncogene 2009;28:3371-9.

36. Izzotti A, Calin GA, Arrigo P, et al. Downregulation of microRNA expression in the lungs of rats exposed to cigarette smoke. FASEB J 2009;23:806-12.

37. Parkin DM, Bray F, Ferlay J, Pisani P. Global cancer statistics, 2002. CA Cancer J Clin 2005;55:74-108.

38. Yu F, Yao H, Zhu P, et al. let-7 regulates self renewal and tumorigenicity of breast cancer cells. Cell 2007;131:1109-23.

39. Shimono Y, Zabala M, Cho RW, et al. Downregulation of miRNA-200c links breast cancer stem cells with normal stem cells. Cell 2009;138:592-603.

40. Yu F, Deng H, Yao H, et al. Mir-30 reduction maintains self-renewal and inhibits apoptosis in breast tumor-initiating cells. Oncogene 2010;29:4194-204.

41. Valastyan S, Reinhardt F, Benaich N, et al. A pleiotropically acting microRNA, miR31 , inhibits breast cancer metastasis. Cell 2009;137:1032-46.

42. Tavazoie SF, Alarcón C, Oskarsson T, et al. Endogenous human microRNAs that suppress breast cancer metastasis. Nature 2008;451:147-52.

43. Sugito N, Ishiguro $\mathrm{H}$, Kuwabara $\mathrm{Y}$, et al. RNASEN regulates cell proliferation and affects survival in esophageal cancer patients. Clin Cancer Res 2006;12:7322-8.

44. Mathé EA, Nguyen GH, Bowman ED, et al. MicroRNA expression in squamous cell carcinoma and adenocarcinoma of the esophagus: associations with survival. Clin Cancer Res 2009;15:6192-200.

45. Volinia S, Calin GA, Liu CG, et al. A microRNA expression signature of human solid tumors defines cancer gene targets. Proc Natl Acad Sci USA 2006;103:2257-61.

46. Schepeler T, Reinert JT, Ostenfeld MS, et al. Diagnostic and prognostic microRNAs in stage II colon cancer. Cancer Res
2008;68:6416-24.

47. Zhang X, Wan G, Mlotshwa S, et al. Oncogenic Wipl phosphatase is inhibited by miR-16 in the DNA damage signaling pathway. Cancer Res 2010;70:7176-86.

48. Yamakuchi M, Lotterman CD, Bao C, et al. P53-induced microRNA-107 inhibits HIF1 and tumor angiogenesis. Proc Natl Acad Sci U S A 2010;107:6334-9.

49. Braun CJ, Zhang X, Savelyeva I, et al. p53Responsive micrornas 192 and 215 are capable of inducing cell cycle arrest. Cancer Res 2008;68:10094-104.

50. Song B, Wang Y, Kudo K, et al. miR-192 Regulates dihydrofolate reductase and cellular proliferation through the p53microRNA circuit. Clin Cancer Res 2008;14:8080-6.

51. Yamakuchi M, Ferlito M, Lowenstein CJ. miR-34a repression of SIRT1 regulates apoptosis. Proc Natl Acad Sci U S A 2008;105:13421-6.

52. Ura S, Honda M, Yamashita T, et al. Differential microRNA expression between hepatitis $B$ and hepatitis $C$ leading disease progression to hepatocellular carcinoma. Hepatology 2009;49:1098-112.

53. Braconi C, Valeri N, Gasparini P, et al. Hepatitis $\mathrm{C}$ virus proteins modulate microRNA expression and chemosensitivity in malignant hepatocytes. Clin Cancer Res 2010;16:957-66.

54. Hou W, Tian Q, Zheng J, Bonkovsky HL. MicroRNA-196 represses Bach1 protein and hepatitis $\mathrm{C}$ virus gene expression in human hepatoma cells expressing hepatitis C viral proteins. Hepatology 2010;51:1494-504.

55. Lanford RE, Hildebrandt-Eriksen ES, Petri A, et al. Therapeutic silencing of microRNA-122 in primates with chronic hepatitis $\mathrm{C}$ virus infection. Science 2010;327:198-201.

56. Szafranska AE, Davison TS, John J, et al. MicroRNA expression alterations are linked to tumorigenesis and non-neoplastic processes in pancreatic ductal adenocarcinoma. Oncogene 2007;26:4442-52.

57. Bloomston M, Frankel WL, Petrocca F, et al. MicroRNA expression patterns to differentiate pancreatic adenocarcinoma from normal pancreas and chronic pancreatitis. JAMA 2007;297:1901-8.

58. Habbe N, Koorstra JB, Mendell JT, et al. MicroRNA miR-155 is a biomarker of early pancreatic neoplasia. Cancer Biol Ther 2009;8:340-6.

59. Yang N, Kaur S, Volinia S, et al. MicroRNA microarray identifies Let-7i as a novel biomarker and therapeutic target in human epithelial ovarian cancer. Cancer Res 2008;68:10307-14.

60. Xia L, Zhang D, Du R, et al. miR-15b and miR-16 modulate multidrug resistance by targeting BCL2 in human gastric cancer cells. Int J Cancer 2008;123:372-9.

61. Ujifuku K, Mitsutake N, Takakura S, et al. miR-195, miR-455-3p and miR-10a $\left(^{*}\right)$ are implicated in acquired temozolomide resistance in glioblastoma multiforme cells. Cancer Lett 2010;296:241-8.

62. Weidhaas JB, Babar I, Nallur SM, et al. MicroRNAs as potential agents to alter resistance to cytotoxic anticancer therapy. Cancer Res 2007;67:11111-6.

63. Kato M, Paranjape T, Müller RU, et al. The mir-34 microRNA is required for the DNA damage response in vivo in $\mathrm{C}$. elegans and in vitro in human breast cancer cells. Oncogene 2009;28:2419-24.

64. Dean M, Fojo T, Bates S. Tumour stem cells and drug resistance. Nat Rev Cancer 2005;5:275-84.

65. Hatfield SD, Shcherbata HR, Fischer KA, et al. Stem cell division is regulated by the microRNA pathway. Nature 2005;435:9748.

66. Tay Y, Zhang J, Thomson AM, et al. MicroRNAs to Nanog, Oct4 and Sox2 coding regions modulate embryonic stem cell differentiation. Nature 2008;455:1124-8.

67. Marson A, Levine SS, Cole MF, et al. Connecting microRNA genes to the core transcriptional regulatory circuitry of embryonic stem cells. Cell 2008;134:52133 .

68. Su H, Yang JR, Xu T, et al. MicroRNA-101, down-regulated in hepatocellular carcinoma, promotes apoptosis and suppresses tumorigenicity. Cancer Res 2009:1135-42.

69. Kondo N, Toyama T, Sugiura H, et al. miR206 Expression is down-regulated in estrogen receptor alpha-positive human breast cancer. Cancer Res 2008;68:50048.

70. Herman JG, Baylin SB. Gene silencing in cancer in association with promoter hypermethylation. N Engl J Med 2003;349: 2042-54.

71. Fabbri M. MicroRNAs and cancer epigenetics. Curr Opin Investig Drugs 2008;9: 583-90.

72. Ting AH, Suzuki H, Cope L, et al. A requirement for DICER to maintain full promoter $\mathrm{CpG}$ island hypermethylation in human cancer cells. Cancer Res 2008;68: 2570-5.

73. Saito Y, Liang G, Egger G, et al. Specific activation of microRNA-127 with downregulation of the proto-oncogene BCL6 by chromatin-modifying drugs in human cancer cells. Cancer Cell 2006;9:435-43.

74. Fazi F, Racanicchi S, Zardo G, et al. Epigenetic silencing of the myelopoiesis regulator microRNA-223 by the AML1/ETO oncoprotein. Cancer Cell 2007; 12:457-66.

75. Fabbri M, Garzon R, Cimmino A, et al. 
MicroRNA-29 family reverts aberrant methylation in lung cancer by targeting DNA methyltransferases 3A and 3B. Proc Natl Acad Sci U S A 2007;104:15805-10.

76. Chen JF, Mandel EM, Thomson JM, et al. The role of microRNA-1 and microRNA133 in skeletal muscle proliferation and differentiation. Nat Genet 2006;38:22833 .

77. Noonan EJ, Place RF, Pookot D, et al. miR449a targets HDAC-1 and induces growth arrest in prostate cancer. Oncogene 2009;28:1714-24.

78. Viswanathan SR, Daley GQ, Gregory RI. Selective blockade of microRNA processing by Lin28. Science 2008;320:97-100.

79. Tokumaru S, Suzuki M, Yamada H, et al. let-7 regulates Dicer expression and constitutes a negative feedback loop. Carcinogenesis 2008;29:2073-7.

80. He L, He X, Lim LP et al. A microRNA component of the p53 tumour suppressor network. Nature 2007;447:1130-4.

81. O'Donnell KA, Wentzel EA, Zeller KI, et al. c-Myc-regulated micoRNAs modulate E2F1 expression. Nature 2005;435:839-43.

82. Mitchell PS, Parkin RK, Kroh EM, et al. Circulating microRNAs as stable bloodbased markers for cancer detection. Proc Natl Acad Sci USA 2008;105: 10513-8.

83. Heneghan HM, Miller N, Lowery AJ, et al. Circulating microRNAs as novel minimally invasive biomarkers for breast cancer. Ann Surg 2010;251:499-505.

84. Huang Z, Huang D, Ni S, et al. Plasma microRNAs are promising novel biomarkers for early detection of colorectal cancer. Int J Cancer 2010;127:118-26.

85. Link A, Balaguer F, Shen Y, ìet al. Fecal MicroRNAs as novel biomarkers for colon cancer screening. Cancer Epidemiol Biomarkers Prev 2010;19:1766-74.

86. Yu L, Todd NW, Xing L, et al. Early detection of lung adenocarcinoma in sputum by a panel of microRNA markers. Int $\mathrm{J}$ Cancer Forthcoming 2010.

87. Xie Y, Todd NW, Liu Z, et al. Altered miRNA expression in sputum for diagnosis of non-small cell lung cancer. Lung Cancer 2010;67:170-6.

88. Park NJ, Zhou H, Elashoff D, et al. Salivary microRNA: discovery, characterization, and clinical utility for oral cancer detection. Clin Cancer Res 2009;15:5473-7.

89. Johnson CD, Esquela-Kerscher A, Stefani $\mathrm{G}$, et al. The let-7 microRNA represses cell proliferation pathways in human cells. Cancer Res 2007;67:7713-22.

90. Kumar MS, Erkeland SJ, Pester RE, et al. Suppression of non-small cell lung tumor development by the let-7 microRNA family. Proc Natl Acad Sci USA 2008;105:39038.

91. Trang P, Medina PP, Wiggins JF, et al.
Regression of murine lung tumors by the let-7 microRNA. Oncogene 2010;29:15807.

92. Bandi N, Zbinden S, Gugger M, et al. miR$15 \mathrm{a}$ and miR-16 are implicated in cell cycle regulation in a $\mathrm{Rb}$-dependent manner and are frequently deleted or downregulated in non-small cell lung cancer. Cancer Res 2009;69:5553-9.

93. Seike M, Goto A, Okano T, et al. MiR-21 is an EGFR-regulated anti-apoptotic factor in lung cancer in never-smokers. Proc Natl Acad Sci U S A 2009;106:12085-90.

94. Hatley ME, Patrick DM, Garcia MR, et al. Modulation of K-Ras-dependent lung tumorigenesis by MicroRNA-21. Cancer Cell 2010;18:282-93.

95. Fabbri M, Garzon R, Cimmino A, et al. MicroRNA-29 family reverts aberrant methylation in lung cancer by targeting DNA methyltransferases 3A and 3B. Proc Natl Acad Sci U S A 2007;104:15805-10.

96. Weiss GJ, Bemis LT, Nakajima E, et al. EGFR regulation by microRNA in lung cancer: correlation with clinical response and survival to gefitinib and EGFR expression in cell lines. Ann Oncol 2008;19:1053-9.

97. Sachdeva M, Mo YY. MicroRNA-145 suppresses cell invasion and metastasis by directly targeting mucin 1 . Cancer Res 2010;70:378-87.

98. Garofalo M, Di Leva G, Romano G, et al. miR-221\&222 regulate TRAIL resistance and enhance tumorigenicity through PTEN and TIMP3 downregulation. Cancer Cell 2009;16:498-509.

99. Patnaik SK, Kannisto E, Knudsen S, Yendamuri S. Evaluation of microRNA expression profiles that may predict recurrence of localized stage I non-small cell lung cancer after surgical resection. Cancer Res 2010;70:36-45.

100. Ma L, Young J, Prabhala H, et al. miR-9, a MYC/MYCN-activated microRNA, regulates E-cadherin and cancer metastasis. Nat Cell Biol 2010;12:247-56.

101. Ma L, Teruya-Feldstein J, Weinberg RA. Tumour invasion and metastasis initiated by microRNA-10b in breast cancer. Nature 2007;449:682-8.

102. Ma L, Reinhardt F, Pan E, et al. Therapeutic silencing of miR-10b inhibits metastasis in a mouse mammary tumor model. Nat Biotechnol 2010;28:341-7.

103. Yu Z, Willmarth NE, Zhou J, et al microRNA 17/20 inhibits cellular invasion and tumor metastasis in breast cancer by heterotypic signaling. Proc Natl Acad Sci U S A 2010;107:8231-6.

104. Lu Z, Liu M, Stribinskis V, et al. MicroRNA-21 promotes cell transformation by targeting the programmed cell death 4 gene. Oncogene 2008;27:4373-9.
105. Gebeshuber CA, Zatloukal K, Martinez J. miR-29a suppresses tristetraprolin, which is a regulator of epithelial polarity and metastasis. EMBO Rep 2009;10:400-5.

106. Bhaumik D, Scott GK, Schokrpur S, et al. Expression of microRNA-146 suppresses NF-kappaB activity with reduction of metastatic potential in breast cancer cells. Oncogene 2008;27:5643-7.

107. Li XF, Yan PJ, Shao ZM. Downregulation of miR-193b contributes to enhance urokinase-type plasminogen activator (uPA) expression and tumor progression and invasion in human breast cancer. Oncogene 2009;28:3937-48.

108. Gregory PA, Bert AG, Paterson EL, et al. The miR-200 family and miR-205 regulate epithelial to mesenchymal transition by targeting ZEB1 and SIP1. Nat Cell Biol 2008;10:593-601.

109. Huang Q, Gumireddy K, Schrier M, et al. The microRNAs miR-373 and miR-520c promote tumour invasion and metastasis Nat Cell Biol 2008;10:202-10.

110. Vetter G, Saumet A, Moes M, et al. miR661 expression in SNAI1-induced epithelial to mesenchymal transition contributes to breast cancer cell invasion by targeting Nectin-1 and StarD10 messengers. Oncogene 2010;29:4436-48.

111. Tian Y, Luo A, Cai Y, et al. MicroRNA-10b promotes migration and invasion through KLF4 in human esophageal cancer cell lines. J Biol Chem 2010;285:7986-94.

112. Hu Y, Correa AM, Hoque A, et al. Prognostic significance of differentially expressed miRNAs in esophageal cancer. Int J Cancer 2010.

113. Kan T, Sato F, Ito T, et al. The miR-106b25 polycistron, activated by genomic amplification, functions as an oncogene by suppressing $\mathrm{p} 21$ and Bim. Gastroenterology 2009;136:1689-700.

114. Kano M, Seki N, Kikkawa N, et al. miR145, miR-133a and miR-133b: Tumor suppressive miRNAs target FSCN1 in esophageal squamous cell carcinoma. Int J Cancer 2010.

115. Luthra R, Singh RR, Luthra MG, et al. MicroRNA-196a targets annexin A1: a microRNA-mediated mechanism of annexin Aldownregulation in cancers. Oncogene 2008;27:6667-78.

116. Lee $\mathrm{KH}$, Goan $\mathrm{YG}$, Hsiao $\mathrm{M}$, et al. MicroRNA-373 (miR-373) post-transcriptionally regulates large tumor suppressor, homolog 2 (LATS2) and stimulates proliferation in human esophageal cancer. Exp Cell Res 2009;315:2529-38.

117. Ueda T, Volinia S, Okumura $\mathrm{H}$, et al. Relation between microRNA expression and progression and prognosis of gastric cancer: a microRNA expression analysis. Lancet Oncol 2010;11:136-46. 
118. Wan HY, Guo LM, Liu T, et al. Regulation of the transcription factor NF-kappaB1 by microRNA-9 in human gastric adenocarcinoma. Mol Cancer 2010;9:16.

119. Luo H, Zhang H, Zhang Z, et al. Down-regulated miR-9 and miR-433 in human gastric carcinoma. J Exp Clin Cancer Res 2009;28:82

120. Zhu LH, Liu T, Tang H, et al. MicroRNA23a promotes the growth of gastric adenocarcinoma cell line MGC803 and downregulates interleukin-6 receptor. FEBS J 2010.

121. Zhang Y, Guo J, Li D, et al. Down-regulation of miR-31 expression in gastric cancer tissues and its clinical significance. Med Oncol 2010;27:685-9.

122. Wang HJ, Ruan HJ, He XJ, et al. MicroRNA-101 is down-regulated in gastric cancer and involved in cell migration and invasion. Eur J Cancer 2010;46:2295303.

123. Feng R, Chen X, Yu Y, et al. miR-126 functions as a tumour suppressor in human gastric cancer. Cancer Lett 2010;298:5063.

124. Wu J, Qian J, Li C, et al. miR-129 regulates cell proliferation by downregulating Cdk6 expression. Cell Cycle 2010;9:180918.

125. Shen R, Pan S, Qi S, et al. Epigenetic repression of microRNA-129-2 leads to overexpression of SOX4 in gastric cancer. Biochem Biophys Res Commun 2010;394: 1047-52.

126. Lai KW, Koh KX, Loh M, et al. MicroRNA$130 \mathrm{~b}$ regulates the tumour suppressor RUNX3 in gastric cancer. Eur J Cancer 2010;46:1456-63.

127. Du Y, Xu Y, Ding L, et al. Down-regulation of miR-141 in gastric cancer and its involvement in cell growth. $\mathrm{J}$ Gastroenterol 2009;44:556-61.

128. Hashimoto Y, Akiyama Y, Otsubo T, et al. Involvement of epigenetically silenced microRNA-181c in gastric carcinogenesis. Carcinogenesis 2010;31:777-84.

129. Wada R, Akiyama Y, Hashimoto Y, et al. miR-212 is downregulated and suppresses methyl-CpG-binding protein MeCP2 in human gastric cancer. Int $\mathrm{J}$ Cancer 2010;127:1106-14.

130. Tie J, Pan Y, Zhao L, et al. MiR-218 inhibits invasion and metastasis of gastric cancer by targeting the Robol receptor. PLoS Genet 2010;6.

131. Gao C, Zhang Z, Liu W, et al. Reduced microRNA-218 expression is associated with high nuclear factor kappa B activation in gastric cancer. Cancer 2010;116: 41-9.

132. Cho WJ, Shin JM, Kim JS, et al. miR-372 regulates cell cycle and apoptosis of ags human gastric cancer cell line through direct regulation of LATS2. Mol Cells 2009;28:521-7.

133. Tsukamoto Y, Nakada C, Noguchi T, et al. MicroRNA-375 is downregulated in gastric carcinomas and regulates cell survival by targeting PDK1 and 14-3-3zeta. Cancer Res 2010;70:2339-49.

134. Jiang Z, Guo J, Xiao B, et al. Increased expression of miR-421 in human gastric carcinoma and its clinical association. $\mathrm{J}$ Gastroenterol 2010;45:17-23.

135. Tsang WP, Kwok TT. The miR-18a* microRNA functions as a potential tumor suppressor by targeting on K-Ras. Carcinogenesis 2009;30:953-9.

136. Wang P, Zou F, Zhang X, et al. microRNA21 negatively regulates $\mathrm{Cdc} 25 \mathrm{~A}$ and cell cycle progression in colon cancer cells. Cancer Res 2009;69:8157-65.

137. Tazawa H, Tsuchiya N, Izumiya M, Nakagama H. Tumor-suppressive miR$34 \mathrm{a}$ induces senescence-like growth arrest through modulation of the E2F pathway in human colon cancer cells. Proc Natl Acad Sci U S A 2007;104:154727.

138. Díaz R, Silva J, García JM, et al. Deregulated expression of miR-106a predicts survival in human colon cancer patients. Genes Chromosomes Cancer 2008;47:794-802.

139. Ng EK, Tsang WP, Ng SS, et al. MicroRNA143 targets DNA methyltransferases 3A in colorectal cancer. $\mathrm{Br} \mathrm{J}$ Cancer 2009;101:699-706.

140. Shi B, Sepp-Lorenzino L, Prisco M, et al. Micro RNA 145 targets the insulin receptor substrate-1 and inhibits the growth of colon cancer cells. Biol Chem 2007;282:32582-90.

141. Valeri N, Gasparini P, Fabbri M, et al. Modulation of mismatch repair and genomic stability by miR-155. Proc Natl Acad Sci U S A 2010;107:6982-7.

142. Schimanski CC, Frerichs K, Rahman F, et al. High miR-196a levels promote the oncogenic phenotype of colorectal cancer cells. World J Gastroenterol 2009;15:208996.

143. Tsang WP, Ng EK, Ng SS, et al. Oncofetal H19-derived miR-675 regulates tumor suppressor RB in human colorectal cancer. Carcinogenesis 2010;31:350-8.

144. Liu WH, Yeh SH, Lu CC, et al. MicroRNA18a prevents estrogen receptor-alpha expression, promoting proliferation of hepatocellular carcinoma cells. Gastroenterology 2009;136:683-93.

145. Kota J, Chivukula RR, O'Donnell KA, et al. Therapeutic microRNA delivery suppresses tumorigenesis in a murine liver cancer model. Cell 2009;137:1005-17.

146. Fornari F, Gramantieri L, Giovannini C, et al. MiR-122/cyclin G1 interaction modu- lates p53 activity and affects doxorubicin sensitivity of human hepatocarcinoma cells. Cancer Res 2009;69:5761-7.

147. Coulouarn C, Factor VM, Andersen JB, et al. Loss of miR-122 expression in liver cancer correlates with suppression of the hepatic phenotype and gain of metastatic properties. Oncogene 2009;28:3526-36.

148. Ding J, Huang S, Wu S, et al. Gain of miR151 on chromosome $8 \mathrm{q} 24.3$ facilitates tumour cell migration and spreading through downregulating RhoGDIA. Nat Cell Biol 2010;12:390-9.

149. Wang B, Hsu SH, Majumder S, et al. TGFbeta-mediated upregulation of hepatic miR-181b promotes hepatocarcinogenesis by targeting TIMP3. Oncogene 2010;29:1787-97.

150. Fornari F, Gramantieri L, Ferracin M, et al. MiR-221 controls CDKN1C/p57 and CDKN1B/p27 expression in human hepatocellular carcinoma. Oncogene 2008;27: 5651-61.

151. Gramantieri L, Fornari F, Ferracin M, et al. MicroRNA-221 targets Bmf in hepatocellular carcinoma and correlates with tumor multifocality. Clin Cancer Res 2009;15:5073-81.

152. Wong QW, Ching AK, Chan AW, et al. MiR222 overexpression confers cell migratory advantages in hepatocellular carcinoma through enhancing AKT signaling. Clin Cancer Res 2010;16:867-75.

153. Wong QW, Lung RW, Law PT, et al. MicroRNA-223 is commonly repressed in hepatocellular carcinoma and potentiates expression of Stathmin1. Gastroenterology 2008;135:257-69.

154. Dillhoff M, Liu J, Frankel W, et al. MicroRNA-21 is overexpressed in pancreatic cancer and a potential predictor of survival. J Gastrointest Surg 2008;12: 2171-6.

155. Ma Y, Yu S, Zhao W, et al. miR-27a regulates the growth, colony formation and migration of pancreatic cancer cells by targeting Sprouty2. Cancer Lett 2010.

156. Yu S, Lu Z, Liu C, et al. miRNA-96 suppresses KRAS and functions as a tumor suppressor gene in pancreatic cancer. Cancer Res 2010;70:6015-25.

157. Lee $\mathrm{KH}$, Lotterman $\mathrm{C}$, Karikari $\mathrm{C}$, et al. Epigenetic silencing of MicroRNA miR107 regulates cyclin-dependent kinase 6 expression in pancreatic cancer. Pancreatology 2009;9:293-301.

158. Li Y, Vandenboom TG 2nd, Wang Z, et al. miR-146a suppresses invasion of pancreatic cancer cells. Cancer Res 2010;70: 1486-95.

159. Gironella M, Seux M, Xie MJ, et al. Tumor protein 53-induced nuclear protein 1 expression is repressed by miR-155, and its restoration inhibits pancreatic tumor 
development. Proc Natl Acad Sci USA 2007;104:16170-5.

160. Greither T, Grochola LF, Udelnow A, et al. Elevated expression of microRNAs 155 , 203,210 and 222 in pancreatic tumors is associated with poorer survival. Int $\mathrm{J}$ Cancer 2010;126:73-80.

161. Laios A, O'Toole S, Flavin R, et al. Potential role of miR-9 and miR-223 in recurrent ovarian cancer. Mol Cancer 2008;7:35.

162. Bhattacharya R, Nicoloso M, Arvizo R, et al. MiR-15a and MiR-16 control Bmi-1 expression in ovarian cancer. Cancer Res 2009;69:9090-5.

163. Fan X, Liu Y, Jiang J, et al. miR-20a promotes proliferation and invasion by targeting APP in human ovarian cancer cells. Acta Biochim Biophys Sin 2010;42:318-24.

164. Li Z, Hu S, Wang J, Cai J, et al. MiR-27a modulates MDR1/P-glycoprotein expression by targeting HIPK2 in human ovarian cancer cells. Gynecol Oncol 2010;119: 125-30.

165. Creighton CJ, Fountain MD, Yu Z, et al. Molecular profiling uncovers a p53-associated role for microRNA-31 in inhibiting the proliferation of serous ovarian carcinomas and other cancers. Cancer Res 2010;70:1906-15.

166. Corney DC, Flesken-Nikitin A, Godwin AK, et al. MicroRNA-34b and MicroRNA$34 \mathrm{c}$ are targets of p53 and cooperate in control of cell proliferation and adhesionindependent growth. Cancer Res 2007;67: 8433-8.

167. Cowden Dahl KD, Dahl R, Kruichak JN, Hudson LG. The epidermal growth factor receptor responsive miR-125a represses mesenchymal morphology in ovarian cancer cells. Neoplasia 2009;11:1208-15.

168. Imam JS, Buddavarapu K, Lee-Chang JS, et al. MicroRNA-185 suppresses tumor growth and progression by targeting the Sixl oncogene in human cancers. Oncogene 2010;29:4971-9.

169. Chen R, Alvero AB, Silasi DA, et al. Regulation of IKKbeta by miR-199a affects NF-kappaB activity in ovarian cancer cells. Oncogene 2008;27:4712-23.

170. Yin G, Chen R, Alvero AB, et al. TWISTing stemness, inflammation and proliferation of epithelial ovarian cancer cells through MIR199A2/214. Oncogene 2010;29:354553.

171. Bendoraite A, Knouf EC, Garg KS, et al. Regulation of miR-200 family microRNAs and ZEB transcription factors in ovarian cancer: evidence supporting a mesothelial-to-epithelial transition. Gynecol Oncol 2010;116:117-25.

172. Giannakakis A, Sandaltzopoulos R, Greshock J, et al. miR-210 links hypoxia with cell cycle regulation and is deleted in human epithelial ovarian cancer. Cancer Biol Ther 2008;7:255-64.

173. Wurz K, Garcia RL, Goff BA, et al. MiR-221 and MiR-222 alterations in sporadic ovarian carcinoma: Relationship to CDKN1B, CDKNIC and overall survival. Genes Chromosomes Cancer 2010;49:577-84.

174. Kefas B, Godlewski J, Comeau L, et al. microRNA-7 inhibits the epidermal growth factor receptor and the Akt pathway and is down-regulated in glioblastoma. Cancer Res 2008;68:3566-72.

175. Sasayama T, Nishihara M, Kondoh T, et al. MicroRNA-10b is overexpressed in malignant glioma and associated with tumor invasive factors, uPAR and RhoC. Int $\mathrm{J}$ Cancer 2009;125:1407-13.

176. Dews M, Fox JL, Hultine S, et al. The MycmiR-17 92 Axis Blunts TGF $\{$ beta $\}$ Signaling and Production of Multiple TGF $\{$ beta $\}$-Dependent Antiangiogenic Factors. Cancer Res 2010;70:8233-46.

177. Ernst A, Campos B, Meier J, et al. Derepression of CTGF via the miR-17-92 cluster upon differentiation of human glioblastoma spheroid cultures. Oncogene 2010;29:3411-22.

178. Chan JA, Krichevsky AM, Kosik KS. MicroRNA-21 is an antiapoptotic factor in human glioblastoma cells. Cancer Res 2005;65:6029-33.

179. Kim H, Huang W, Jiang X, et al. Integrative genome analysis reveals an oncomir/oncogene cluster regulating glioblastoma survivorship. Proc Natl Acad Sci USA 2010;107:2183-8.

180. Godlewski J, Nowicki M0, Bronisz A, et al. Targeting of the Bmi-1 oncogene/stem cell renewal factor by microRNA-128 inhibits glioma proliferation and selfrenewal. Cancer Res 2008;68:9125-30.

181. Xu J, Liao X, Wong C. Downregulations of B-cell lymphoma 2 and myeloid cell leukemia sequence 1 by microRNA 153 induce apoptosis in a glioblastoma cell line DBTRG-05MG. Int J Cancer 2010;126: 1029-35.

182. Guan Y, Mizoguchi M, Yoshimoto K, et al. MiRNA-196 is upregulated in glioblastoma but not in anaplastic astrocytoma and has prognostic significance. Clin Cancer Res 2010;16:4289-97.

183. Medina R, Zaidi SK, Liu CG, et al. MicroRNAs 221 and 222 bypass quiescence and compromise cell survival. Cancer Res 2008;68:2773-80.

184. Ueda R, Kohanbash G, Sasaki K, et al. Dicer-regulated microRNAs 222 and 339 promote resistance of cancer cells to cytotoxic T-lymphocytes by down-regulation of ICAM-1. Proc Natl Acad Sci USA 2009;106: 10746-51.

185. Würdinger T, Tannous BA, Saydam 0, et al. miR-296 regulates growth factor receptor overexpression in angiogenic endothelial cells. Cancer Cell 2008;14:382-93.

186. Shin S, Cha HJ, Lee EM, et al. Alteration of miRNA profiles by ionizing radiation in A549 human non-small cell lung cancer cells. Int J Oncol 2009;35:81-6.

187. Sun M, Estrov Z, Ji Y, et al. Curcumin (diferuloylmethane) alters the expression profiles of microRNAs in human pancreatic cancer cells. Mol Cancer Ther 2008;7:464-73.

188. Galluzzi L, Morselli E, Vitale I, et al. miR181a and miR-630 regulate cisplatininduced cancer cell death. Cancer Res 2010;70:1793-803.

189. Zhu W, Shan X, Wang T, et al. miR-181b modulates multidrug resistance by targeting BCL2 in human cancer cell lines. Int J Cancer 2010;127:2520-9.

190. Zhang H, Li M, Han Y, et al. Down-regulation of miR-27a might reverse multidrug resistance of esophageal squamous cell carcinoma. Dig Dis Sci 2010;55:2545-51.

191. Hong L, Han Y, Zhang H, et al. The prognostic and chemotherapeutic value of miR-296 in esophageal squamous cell carcinoma. Ann Surg 2010;251:1056-63.

192. Chun-Zhi Z, Lei H, An-Ling Z, et al. MicroRNA-221 and microRNA-222 regulate gastric carcinoma cell proliferation and radioresistance by targeting PTEN. BMC Cancer 2010;10:367.

193. Bandres E, Bitarte N, Arias F, et al. microRNA-451 regulates macrophage migration inhibitory factor production and proliferation of gastrointestinal cancer cells. Clin Cancer Res 2009;15:228190.

194. Song B, Wang Y, Xi Y, et al. Mechanism of chemoresistance mediated by miR-140 in human osteosarcoma and colon cancer cells. Oncogene 2009;28:4065-74.

195. Borralho PM, Kren BT, Castro RE, et al. MicroRNA-143 reduces viability and increases sensitivity to 5 -fluorouracil in HCT116 human colorectal cancer cells. FEBS J 2009;276:6689-700.

196. Song B, Wang Y, Titmus MA, et al. Molecular mechanism of chemoresistance by miR-215 in osteosarcoma and colon cancer cells. Mol Cancer 2010;9:96.

197. Ji J, Shi J, Budhu A, et al. MicroRNA expression, survival, and response to interferon in liver cancer. $\mathrm{N}$ Engl $\mathrm{J}$ Med 2009;361:1437-47.

198. Fornari F, Milazzo M, Chieco P, et al. MiR199a-3p regulates mTOR and c-Met to influence the doxorubicin sensitivity of human hepatocarcinoma cells. Cancer Res 2010;70:5184-93.

199. Ali S, Ahmad A, Banerjee S, et al. Gemcitabine sensitivity can be induced in 
pancreatic cancer cells through modulation of miR-200 and miR-21 expression by curcumin or its analogue CDF. Cancer Res 2010;70:3606-17.

200. Hwang JH, Voortman J, Giovannetti E, et al. Identification of microRNA-21 as a biomarker for chemoresistance and clinical outcome following adjuvant therapy in resectable pancreatic cancer. PLoS One 2010;5.

201. Moriyama T, Ohuchida K, Mizumoto K, et al. MicroRNA-21 modulates biological functions of pancreatic cancer cells including their proliferation, invasion, and chemoresistance. Mol Cancer Ther 2009;8:1067-74.

202. Li Z, Hu S, Wang J, et al. MiR-27a modulates MDR1/P-glycoprotein expression by targeting HIPK2 in human ovarian cancer cells. Gynecol Oncol 2010;119:125-30.

203. Nagaraja AK, Creighton CJ, Yu Z, et al. A link between mir-100 and FRAP1/mTOR in clear cell ovarian cancer. Mol Endocrinol 2010;24:447-63.

204. Cochrane DR, Spoelstra NS, Howe EN, et al. MicroRNA-200c mitigates invasiveness and restores sensitivity to microtubule-targeting chemotherapeutic agents. Mol Cancer Ther 2009;8:1055-66.

205. Shi L, Chen J, Yang J, et al. MiR-21 protected human glioblastoma U87MG cells from chemotherapeutic drug temozolomide induced apoptosis by decreasing Bax/Bcl-2 ratio and caspase-3 activity.
Brain Res 2010;1352:255-64.

206. Li Y, Li W, Yang Y, et al. MicroRNA-21 targets LRRFIP1 and contributes to VM-26 resistance in glioblastoma multiforme. Brain Res 2009;1286:13-8.

207. Lu L, Katsaros D, de la Longrais IA, et al. Hypermethylation of let-7a-3 in epithelial ovarian cancer is associated with low insulin-like growth factor-II expression and favorable prognosis. Cancer Res 2007;67:10117-22.

208. Datta J, Kutay H, Nasser MW, et al. Methylation mediated silencing of MicroRNA-1 gene and its role in hepatocellular carcinogenesis. Cancer Res 2008;68:5049-58.

209. Lehmann U, Hasemeier B, Christgen M, et al. Epigenetic inactivation of microRNA gene hsa-mir-9-1 in human breast cancer. J Pathol 2008;214:17-24.

210. Lujambio A, Calin GA, Villanueva A, et al. A microRNA DNA methylation signature for human cancer metastasis. Proc Natl Acad Sci U S A 2008;105:13556-61.

211. Bandres E, Agirre X, Bitarte N, et al. Epigenetic regulation of microRNA expression in colorectal cancer. Int $\mathrm{J}$ Cancer 2009;125:2737-43

212. Toyota M, Suzuki H, Sasaki Y, et al. Epigenetic silencing of microRNA-34b/c and B-cell translocation gene 4 is associated with CpG island methylation in colorectal cancer. Cancer Res 2008;68:4123-32.

213. Lujambio A, Ropero S, Ballestar E, et al.
Genetic unmasking of an epigenetically silenced microRNA in human cancer cells. Cancer Res 2007;67:1424-9.

214. Huang YW, Liu JC, Deatherage DE, et al. Epigenetic repression of microRNA-129-2 leads to overexpression of SOX4 oncogene in endometrial cancer. Cancer Res 2009;69:9038-46.

215. Balaguer F, Link A, Lozano JJ, et al. Epigenetic silencing of miR-137 is an early event in colorectal carcinogenesis. Cancer Res 2010;70:6609-18.

216. Meng F, Wehbe-Janek H, Henson R, et al. Epigenetic regulation of microRNA-370 by interleukin-6 in malignant human cholangiocytes. Oncogene 2008;27:37886.

217. Saito Y, Suzuki H, Tsugawa H, et al. Chromatin remodeling at Alu repeats by epigenetic treatment activates silenced microRNA-512-5p with downregulation of Mcl-1 in human gastric cancer cells. Oncogene 2009;28:2738-44.

218. Garzon R, Liu S, Fabbri M, et al. MicroRNA-29b induces global DNA hypomethylation and tumor suppressor gene reexpression in acute myeloid leukemia by targeting directly DNMT3A and $3 \mathrm{~B}$ and indirectly DNMT1. Blood 2009;113:6411-8.

219. Duursma AM, Kedde M, Schrier M, et al. miR-148 targets human DNMT3b protein coding region. RNA 2008;14:872-7. 